\title{
An account of Common Broomrape Orobanche minor (Orobanchaceae) in the British Isles
}

\author{
C.J. Thorogood ${ }^{1,2^{*}}$, Fred Rumsey ${ }^{3}$ \\ ${ }^{1}$ University of Oxford Botanic Garden, Oxford, UK; ${ }^{2}$ Department of Plant Sciences, \\ University of Oxford, Oxford, UK; ${ }^{3}$ Natural History Museum, London, UK.
}

*Corresponding author: Chris Thorogood: chris.thorogood@obg.ox.ac.uk

This pdf constitutes the Version of Record published on $31^{\text {st }}$ August 2020

\begin{abstract}
Common broomrape (Orobanche minor Sm.) is the most widespread and variable species in the British Isles and is the subject of much taxonomic confusion. Poor preservation in herbaria, coupled with the presence of cryptic host-specific races, have contributed to this. Here we review the taxonomic status of infraspecific taxa of $O$. minor in the British Isles, and provide a revised identification key, informed by morphology, ecology and molecular data. We describe two new varieties of 0 . minor s.l. that are ecologically distinct and discuss within the broader context of cryptic taxa in the subsection Minores (Beck-Mannagetta) Teryokhin in the British Isles and continental Europe. We suggest that delineating taxa objectively and reliably will be important for informing conservation priorities. Host identity and ecology, besides morphology, are essential considerations when identifying infraspecific taxa in this taxonomically challenging species.
\end{abstract}

Keywords: Taxonomy; host race; parasitic plant

\section{Introduction}

Broomrapes (genus Orobanche L.) are renowned for being taxonomically challenging. Many of the characters useful for identification, for example stigma and corolla colour, are lost upon drying. Coupled with inadequate field notes, herbarium specimens are often determined incorrectly (Rumsey \& Jury, 1991). Of the 14 species that occur in the British Isles, common broomrape (Orobanche minor Sm.) is the most widespread and variable (Figs. $1 \& 3$ ). It is ephemeral across much of its range, sometimes introduced with seed mixes, and can appear erratically in large numbers, often on recently disturbed sites and among clovers in grassland (Fig. 1A). It is a highly variable and taxonomically complex species throughout its range (see for example the treatment by Beck-Mannagetta, 1930). Infraspecific taxa of $O$. minor s.l. show varying levels of morphological and ecological distinctiveness. For example 0 . minor subsp. maritima (Pugsley) Rumsey is most probably native and restricted largely to steep calcareous sea cliffs in southern Britain where it grows almost exclusively on sea carrots (Daucus carota L. subsp. gummifer (Syme) Hook. f. (Fig. 1B). Meanwhile the host generalist 0 . minor Sm. subsp. minor is widespread across Europe and the Mediterranean and grows in various habitats (Kreutz, 1995). The indigenous range of 0 . minor s.l. in the British Isles is unclear owing to repeated 
introductions (Rumsey and Jury, 1991; Preston et al., 2002). It can infect multiple hosts, which may in part explain the unusually wide distribution of this species (Thorogood et al., 2009a), although within this taxonomic entity there exist a multiplicity of races adapted to particular hosts, reinforced by selfing, that might be regarded as incipient species. Therefore, in its broadest circumscription, 0 . minor s.l. comprises multiple taxa some of which may be morphologically indistinct, but which have distinct host ranges, ecologies, evolutionary histories and distributions.

How these cryptic taxa are treated taxonomically is open to debate. Here we provide a brief account of the taxonomic status of $O$. minor in the British Isles, along with a revised identification key informed by morphological, ecological and molecular data. We describe two variants of $\boldsymbol{O}$. minor for the first time that are ecologically, and (at least partially) morphologically distinct. Composite photographs and drawings of taxa referred to in this paper are included at the end of the text (Figs. 14).

\section{Host range and specificity}

The identity of the host is often cited as an important diagnostic in the genus Orobanche because most species have a narrow host range (Schneeweiss, 2007; Schneider et al., 2016). However, in mixed vegetation it is often impossible to identify the host reliably. Moreover, unlike most species in the genus, 0 . minor s.l. is known to infect a diverse range of flowering plants from at least 16 orders of both monocots and eudicots (Thorogood et al., 2009a) meaning that the diagnostic is apparently of limited value for this species.

The nature of and extent to which the phenotype of Orobanche is influenced by the host is not clear. Orobanche minor shows differences in morphology and vigour when cultivated on different hosts (Musselman and Parker 1982). Furthermore, empirical evidence has demonstrated that populations of subsp. minor and subsp. maritima are locally adapted to their allopatric hosts and are genetically distinct (Thorogood et al., 2008, 2009b). Together, this work suggests that 0 . minor s.l. comprises multiple taxa, the extent of which may have been obscured by cryptic morphology. How such distinct lineages are treated taxonomically, i.e. at which rank, can be controversial. Recent approaches have shown a greater tendency than the earlier conservative treatment of Chater \& Webb (1972) to treat host specific races within the genus as distinct species, these often demonstrating both a narrow geographical and host range. This has led to a spate of new species being described in the Mediterranean, Asia Minor and the Middle East in the last two decades (see for example: Pujadas-Salva \& Crespo, 2004; Pujadas-Salva et al., 2005, PujadasSalva et al., 2008; Domina \& Danin, 2014; Zare \& Dönmez, 2014; Piwowarczyk, 2015). Delineating taxa objectively and reliably is important for informing ecological surveys and for setting conservation priorities: for example in the British Isles, the native subsp. maritima is of greater conservation concern than neophytic forms introduced through urban landscaping. Host range (where known), as well as ecology and morphology, must therefore be taken into account when identifying closely related broomrapes.

\section{The infraspecific taxa of 0 . minors.l.}

Orobanche minor belongs to the subsection Minores (Beck-Mannagetta) Teryokhin (1997) - a group of similar, small-flowered species (with corollas typically $<20 \mathrm{~mm}$ ) 
that are notoriously challenging to identify in the field, and that preserve poorly in herbaria. Beck-Mannagetta (1930), in the last comprehensive monograph of the genus, recognised 20 species within his grex Minores and included descriptions of a further six which he considered plausible but too poorly known. In addition, at the infraspecific level he recognised 20 varieties and a total of 69 forms; he did not employ subspecific rank anywhere within the treatment. The extent of taxonomic and nomenclatural difficulties presented by this group is indicated by the fact that within his index, Beck-Mannagetta (1930) lists over 345 binomials as pertaining to this grex. Three species belonging to this group occur in the British Isles (Figs. 2, 4): the widespread $O$. minor and the rare $O$. picridis F.W. Schultz (Figs. 2A, 2C, 4D), which co-occur in Kent, and $O$. hederae Duby (Figs. 2F-G; 4E), which is most frequent in the southwest. Rumsey and Jury (1991) described four infraspecific taxa of 0 . minor in the British Isles at the varietal rank: var. minor, var. flava E. Regel, var. compositarum Pugsley and var. maritima (Pugsley) Rumsey, the latter of which was later elevated to subsp. maritima (Rumsey, 2007). Here we assess the status of these taxa (Fig. 3), in light of new data, and in the broader context of subsection Minores (Beck- Mannagetta) Teryokhin.

\section{1) Orobanche minor Sm. subsp. maritima (Pugsley) Rumsey (2007) Watsonia 26:474.}

Basionym: O. maritima Pugsley (1940) J. Bot. (Lond.) 78:110.

Flowering stem 10-30(-40) cm, strongly pigmented with purple, glandularpuberulent, usually with a pronounced bulbous base from which several stems may arise. Flowers few to many in a dense spike. Bracts $8-16 \mathrm{~mm}$, lanceolate from a broad base, usually not exceeding the corollas. Calyx 6-10 mm, entire or unequally bifid. Corolla 10-17 mm, sparsely glandular, sharply inflected at base; upper lip entire to emarginate; lower lip with middle lobe the largest, reniform, with pronounced yellowish bosses; all lobes crisped and denticulate. Filaments glabrous to sparsely hairy below, inserted 2-3 $\mathrm{mm}$ above the corolla base. Stigma lobes partially united, purple. Flowering period late May to early August.

This British native was described originally at the species level by Pugsley (1940) although recognised as distinct by earlier British botanists, but wrongly equated with the continental O. amethystea Thuill. (Rumsey \& Jury, 1991). Having previously reduced the species to varietal rank, Rumsey (2007) revised the status to the subspecific level, and suggested that a distinctive yellow form, described from Jersey, belonged to this taxon (O. minor subsp. maritima var. hypochoeridis (Beck) Rumsey (see below). The distinctiveness of subsp. maritima from subsp. minor is corroborated by both morphological and DNA sequence data that support their distinction at the sub-specific rank (Thorogood et al., 2008; Thorogood et al., 2009a). DNA sequence data of accessions from across Europe have identified a geographically widespread lineage of 0 . minor (which can be ascribed to 0 . minor subsp. minor, see below) and, interestingly, a genetic similarity between North European populations of 0 . minor subsp. maritima with the poorly known species $O$. litorea Guss., based on material from Sicily (Fig. 4A) (Thorogood et al., 2009a). Morphological similarities are also apparent with 0 . minor var. flavescens Reut., treated by Beck-Mannagetta (1930) within his f. crithmi-maritimi Beck of 0 . minor var. minor [as var. typica]. This plant, described from North Africa and southern 
Spain, is, as the name suggests, also apparently primarily a parasite of coastal Apiaceae. In his original description Pugsley indicated the occurrence of 0 . maritima in Gibraltar. Foley (2001) in Flora Iberica suggested that plants from Cape St. Vincent in Portugal growing on Plantago coronopus L. may belong to maritima; here it co-occurs with another species in the subsection Minores, $O$. calendulae Pomel (Fig. $2 \mathrm{~K}$ ) - a poorly known species that seems to grow almost exclusively on Calendula on sea cliffs. Thorogood et al., (2009a) highlighted similarities between 0 . litorea Guss. and the populations on $P$. coronopus (a known host of $O$. minor subsp. maritima) (Fig. 2J, 4B). Raab-Straube and Raus (2018) agreed and ascribed this Portuguese taxon to $O$. litorea (albeit without molecular data). The possibility of $O$. litorea occurring in Portugal, and the genetic relatedness of Sicilian $O$. litorea with British O. minor subsp. maritima (Thorogood et al., 2009a), together indicate the divergence of a widespread maritime lineage of locally host-specific races from a more generalist continental 'stock' of 0 . minor s.I. Broad-scale sampling from coastal populations around Europe, along with advanced technologies such as a hyb-seq NGS-based approach, could be employed to test this hypothesis rigorously. If they are shown to be conspecific and deemed worthy of specific rank, Gussone's epithet, dating from 1828 (Gussone, 1828), would take nomenclatural priority.

2) Orobanche minor Sm. var. hypochoeridis (Beck) Rumsey in Watsonia 26:476. (2007)

Basionym: O. major L. forma hypocheridis Beck in Fedde, Rep. 18:36 (1922)

Flowering stem 8-18(-25) cm, glandular-pubescent, yellow. Spike dense sometimes sub-globose. Bracts 6-14 mm, ovate lanceolate, equalling corollas. Calyx 6-10 mm, entire almost filiform. Corolla 10-14 mm, sparsely glandular, curved throughout but most sharply inflected at the base. Upper lip emarginate, lobes forwardly directed; lower lip with +/-subequal lobes, all crisped and denticulate. Filaments sub-glabrous, inserted 3-3.5 mm above corolla base. Stigma lobes yellow, touching at base.

Flowering period early June to mid-July.

This intriguing plant has been much-confused with other yellow (anthocyanindeficient) forms of $O$. minor s.l. and was called $O$ minor. var. flava $\mathrm{E}$. Regel in earlier British Floras (eg. Clapham et al., 1952) but originally had been likened not to $O$. minor but to 0 . ritro Gren. \& Godr., a taxon of contested status usually synonymised with $O$. elatior Sutton. A detailed account of the taxonomic history of this taxon is given by Rumsey (2007). Known only with certainty from the Channel Islands, described from fixed dunes on Jersey (Figs. 1J, 3B, 3H), the plant has also been recorded from similar situations on Alderney and with some doubt from Guernsey. Although associated by Rumsey with the native subsp. maritima and not the possibly alien subsp. minor, in its choice of host, Hypochaeris and related Asteraceae of the tribe Cichorieae, it showed greater similarity to the latter. We believe that varietal as opposed to forma status is warranted, as the lack of anthocyanins, which is a feature demonstrated by scattered examples of most Orobanche taxa, is here linked with distinct morphological features: plant short (often $<15 \mathrm{~cm}$ ) with conspicuous stem bracts and with a dense, globose head of short corollas with comparatively high filament insertion and entire rather narrow calyx segments. The plant was recorded last from the type locality in Jersey in 1951 and is possibly extinct; this has hampered the use of molecular data and more considered study. More recently a 
superficially similar plant, provisionally treated under this taxon by Rumsey \& Jury (1991), has been found repeatedly in Newport Docks, v.c.35 (Fig. 1I). Here it occurs on sandbanks and sidings, and also (sporadically) on adjacent roadsides; specimens from this site have been cultivated on clovers at the University of Bristol Botanic Garden. DNA sequencing of material from Newport Docks indicates possible relatedness to both subsp. minor and subsp. maritima, suggesting possible gene flow between them (Thorogood et al., 2009a). The conspecificity of the Newport plant with the Channel Island taxon requires further analysis. However, in the absence of extant populations from the type locality it may be impossible to say whether similar gene flow, which might account for its host shift, had occurred there. While the Newport plant has yellow spikes that are apically globose, the plants are often larger, the inflorescence laxer below, with rather larger corollas of a shape more reminiscent of subsp. minor (with which the plant apparently cooccurs); the plants are also parasitising Fabaceae. Further work is required before the plants in Newport can be assigned unequivocally to subsp. minor (as forma lutea), or to subsp. maritima (as var. hypochoeridis).

\section{3) Orobanche minor Sm. var. minor in English Botany 6 (1797).}

Flowering stems simple, (5-)10-60 cm, glandular-puberulent to hairy, yellowish or reddish-brown, tinged to a variable degree with purple. Spike lax to dense. Bracts 6$22 \mathrm{~mm}$, ovate-lanceolate to lanceolate-subulate, acuminate, equalling to just exceeding the corolla. Calyx 6-14 mm long, equally to unequally bifid, rarely entire. Corolla $10-18(-20) \mathrm{mm}$, creamy-yellow, curved regularly throughout or sharply inflected at the base then curved, purplish suffused to a variable extent, glandularpubescent to glabrous, upper lip emarginate or slightly bilobed with the lobes directed forwards; lobes of lower lip sub-equal or with the central the largest, all lobes crisped and denticulate, without prominent bosses. Stamens inserted 2-3.5 $\mathrm{mm}$ above the corolla base; filaments glabrous to sparsely hairy below. Stigma lobes typically pinkish-purple, to reddish-purple (or yellow in all-yellow variants), just touching at the base to partially united. Flowering period late May to midSeptember. $n=19,2 n=38$.

This is a highly variable and widespread plant that is possibly not native to the British Isles. Interestingly its clearest claims to native status are provided by those persistent populations in coastal areas, on fixed dunes and shingle where it is sometimes sympatric with subsp. maritima, $O$. picridis F.W. Schultz and $O$. hederae Duby, and can form somewhat distinctive populations on particular native host species, e.g. Eryngium maritimum L. (see below). Otherwise it is often casual or sporadic and particularly common on roadsides, in disused chalk and gravel pits, sown leys and amenity plantings. Repeated introductions from disparate sources, cryptic race formation driven by host specificity, and possible hybridisation among races, may all have contributed to the long-standing taxonomic confusion associated with this variable subspecies. It is often confused with $O$. hederae (Figs. 2F-G, 4E), the host of which (typically Hedera hibernica (G. Kirchn.) Bean but occasionally other species such as Eryngium), may not always be apparent. This species differs in its yellowish stigma, corollas with a distinct constriction behind the corolla mouth and more acute and lacerate corolla lower lip lobes. That plant also has a more protracted flowering period (into autumn), markedly swollen subterranean stem and 
prominent spike apex of the immature flowers. The very rare 0 . picridis (Figs. 2A, $2 \mathrm{C}, 4 \mathrm{D}$ ) is also easily mistaken for $O$. minor. It differs in its predominantly ivorycoloured corollas that contrast the dark-purple stigmas, porrect upper lip lobes, filiform calyx segments and copious long white hairs on the filaments. The stems are typically rather slender, the corollas proportionately larger than in 0 . minor and British plants are found almost exclusively on Picris hieracioides $\mathrm{L}$. Robust plants of $O$. minor parasitic on thistles are also often mistakenly recorded for $O$. reticulata Wallr. (which in the British Isles is almost entirely restricted to magnesian limestone in Yorks). This species differs in its corollas which are broadly cylindricalcampanulate in shape and have distinct dark glands.

As discussed above under $\boldsymbol{O}$. minor subsp. maritima, almost all Orobanche species produce variants in which the purplish anthocyanin pigments are absent and in both 0 . minor s.l. and $O$. hederae, striking pure yellow forms are not infrequent. These differ from the typical plants only in their colouration. They show no difference in ecology, or host and have a distribution that is more or less interspersed throughout the range of the species. Indeed, the sheet bearing the type of 0 . minor Sm. at LINN also contains yellow individuals. Whether these colour forms arise de novo from different 'typical' populations independently, or are of common origin remains to be examined. It is clear however that yellow forms may form distributional 'hot spots' through local dispersal as seen in $O$. hederae $\mathrm{f}$. monochroa Beck in N. Hants (Fig. 2G). In this they show similarities to the colourmorphs/corolla shape variants of the bee orchid Ophrys apifera Huds. (Orchidaceae), another Sub-Mediterranean-Sub-Atlantic, predominantly selfing species of ruderal and disturbed habitats. The rank at which such variants should be recognised is controversial. Yellow specimens of $O$. minor traditionally have been accorded varietal rank; the earliest epithet at this rank being var. flava E. Regel (1842). However Beck-Mannagetta (1890) chose incorrectly to combine Duby's earlier specific epithet concolor Duby and treat both Regel's plant and Tourlet's later var. lutea from 1903 (Tourlet, 1903) as synonyms of it in his monograph of 1930 . We consider it best to treat these purple pigment-deficient plants, (that may have multiple independent origins), as a form, rather than at the varietal rank. Tourlet's type clearly conforms to our concept of this taxon; it is digitised and accessible online (see Delaunay \& Rideau, 2018) and has a very apt epithet. We thus make the necessary combination at the forma level below.

4) Orobanche minorf. Iutea (Tourlet) Thorogood \& Rumsey Stat.nov. Basionym: Orobanche minor Sm. var. lutea Tourlet (1903) in Bull. Bot. Soc. France 50:421-2.

As per subsp. minor var. minor but plant lacking purple pigmentation, yellow in all its parts. (Pale plants of $O$. minor with creamy-white flowers and yellowish stems but still retaining vestiges of pinkish-purple in the stigma are best-recorded as $O$. minor s.s. They are confused easily with $O$. picridis).

5) Orobanche minor var. compositarum Pugsley in J. Bot. (Lond.) 78:111(1940)

Flowering stems $10-50 \mathrm{~cm}$, slender, glandular pubescent to sub-glabrous, usually pale reddish-brown. Spike usually lax throughout, rarely dense. Bracts and calyx as 
in var. minor. Corolla $10-16(-18) \mathrm{mm}$ slenderer than in var. minor (width to c.5mm), sub-glabrous, sub-erect not horizontal at anthesis, less heavily pigmented. Filaments somewhat hairy below. Other characters as var. minor. Host usually Crepis spp. (Asteraceae).

Pugsley (1940) described var. compositarum as a distinct variant of 0 . minor distinguished by its narrower, paler, sub-erect corollas and distinctly hairy filament bases (Figs. 3A, 3G). In their hairier filaments, pale flowers and host range these plants had been the source of confusion with $O$. picridis. Plants with these characters have been recorded most frequently on sandy soils in Surrey and East Anglia, but also in coastal areas elsewhere, especially on Crepis capillaris Wallr. and other Asteraceae. The temptation to assign any plant to this taxon that is found growing on a composite host, or plants post-anthesis with somewhat erect drying flowers and capsules, has resulted in mis-recording and an unclear picture as to this plant's true distribution and conservation status. Examination of material indicated by Pugsley as paratypes at BM! shows considerable variation, with at least one example apparently parasitic on Trifolium. Given its stated specificity for a range of native hosts in seminatural open habitats, a case could be made for this taxon as being native, particularly if a coherent geography rather than a random distribution could be demonstrated. Efforts to locate populations by the authors across East Anglia in 2010 to include in analyses were fruitless and the taxon has not been DNAsequenced or cultivated in growth trials. Its level of distinctiveness and status is therefore unclear, however given its morphology and ecology, we maintain this taxon at the varietal rank. Specimens on Brachyglottis (described below) do also produce sub-erect corollas when in fruit; it is possible that these forms are closely related, or that a shift in host has taken place from native herbaceous Asteraceae to this cultivated shrubby host, following the widespread introduction of the Brachyglottis hybrid for amenity planting in recent decades. Further work should examine var. compositarum together with this plant (which we describe below as var. heliophila) in greater detail to establish their level of relatedness.

For many botanising in urban areas of the British Isles their main exposure to the genus is finding populations of $O$. minor subsp. minor on Brachyglottis $\times$ jubar P.D. Sell 'Sunshine' - a cultivated shrub from New Zealand (previously often referred to incorrectly as Senecio greyii). This is planted frequently in carparks, gardens and other landscaped areas across the British Isles and through much of this cultivated range the parasite may now be found. Such specimens are often clumped and robust (Figs. 1C-E) and showing signs of perennation, possibly a consequence of parasitising a large, shrubby host (O. minor is generally found on herbaceous hosts). They also have rather strongly pigmented corolla tubes and hairy filaments, but these features are continuously variable in 0 . minor s.l. Growth trials using seed collected from populations on Brachyglottis show that the plant does not develop on Trifolium pratense L. (a 'typical' host of $O$. minor s.l.) indicating that those growing on the shrub comprise a physiologically distinct race, despite lacking clearly defining morphological features (CJ Thorogood, unpublished data).

As the Brachyglottis Dunedin hybrids were only introduced to the British Isles after 1910 (Bean, 1980) and the parental species are native to an area, New Zealand, where no native Orobanche species occur, the adaptation to this host has clearly been a very recent one. Its distribution outside of the British Isles is unknown. 
Given the demonstrable host specificity, and associated ecology and lifehistory, we here treat these populations as a distinct variety of the widespread subspecies, and describe it as $O$. minor var. heliophila the epithet 'sun loving' referencing the cultivar name 'Sunshine' of its predominant host.

\section{6) O. minor Sm. var. heliophila Thorogood \& Rumsey, var. nov.}

Type: E. Kent, VC.15; Dover, in flower beds bordering the A2 and seafront promenade, close to exit from ferry terminal, parasitic on Brachyglottis $\times$ jubar, $51^{\circ} 07^{\prime} 30.8^{\prime \prime N} 1^{\circ} 19^{\prime} 24.7^{\prime \prime E}(51.125218,1.323516), 25 / 06 / 2020$. C. Thorogood \& F. J. Rumsey s.n. BM (BM013848255)

A more or less robust annual, or weak perennial. Flowering stems 1-5(10), typically clumped from the base, (5-)15-60(70) cm (clumps often with spikes of varying height), glandular-pubescent, yellowish below, reddish-brown to purple above. Stems scarcely swollen below. Spike lax to dense; usually lax below and dense to crowded apically in larger specimens. Bracts $9-22 \mathrm{~mm}$, ovate-lanceolate to lanceolate-subulate, acuminate, equalling to just exceeding the corolla. Calyx purple, 6-14 mm long, equally to unequally bifid. Corolla $10-18 \mathrm{~mm}$, glandular-pubescent, basally white, conspicuously flushed and veined with purple towards the upper 1/3 or $1 / 2$, curved regularly throughout or inflected at the base then curved, upper lip emarginate to bilobed with the lobes often slightly reflexed; lobes of lower lip subequal, all lobes strongly crisped to sub-crenate-denticulate; corolla erecto-patent to sub-erect in fruit. Stamens inserted 2-3 mm above the corolla base; filaments typically white-hairy below. Styles purplish, reflexed apically (especially when mature). Stigma lobes slightly exserted, pinkish-purple to purplish-orange, rather distant. Flowering period late May to mid-September.

Parasitic on Brachyglottis $\times$ jubar and occasionally other shrubs (such as Veronica spp.) in cultivated and landscaped habitats. Frequent in car parks and gardens throughout the British Isles except for the far north; most common in the southeast. Distinguished by its host preference, clumped, frequently perennial individuals, hairier filaments and pattern of pigmentation.

Material ascribable to 0 . minor subsp. maritima was recorded under the name O. amethystea Thuill. in the nineteenth century (Hore 1845), which is a related continental species that is absent from the British Isles and parasitic mainly on Eryngium spp. (Fig. 2I). Adding to this confusion, populations of $O$. minor subsp. minor in east Kent and elsewhere in Britain and Ireland (e.g. Anderson, 1997) growing on Eryngium maritimum L. do show superficial similarities to $O$. amethystea, which is how they were recorded by Philp (1982). They have long, dense, purple spikes of large flowers (to c.20mm) with corollas with a rather flat dorsal line and geniculate tip, and bilobed upper lips (Figs.1F-G; 3E). They also show a level of ecological distinctiveness, growing on coastal dunes and shingle, where they are parasitic on various halophytes besides E. maritimum, including Ononis repens L., Calystegia soldanella (L.) R. Br., Honckenya peploides (L.) Ehrh. and Crithmum maritimum $\mathrm{L}$. Similar populations growing on $E$. maritimum also occur on sand dunes in the north of France, Belgium and the Netherlands (Thorogood $\mathrm{CJ}$, pers. obs). The status of the British populations have long been controversial and seem to show variability correlated with host identity (Rumsey, 2007). Corroborated by morphological and molecular data (Thorogood et al., 2008; 2009a), we treat these 
populations as a variety of the widespread and variable subsp. minor. Of the numerous forms accepted by Beck-Mannagetta these plants come closest to forma procerior Reichenb. recorded as parasitizing Dipsacus and Leucanthemum, etc. and distinguished by its luxuriance and larger, flatter-backed corollas. We however hesitate to equate our plants with this, differing as they do in host and some aspects of floral morphology and choose to describe them here as Orobanche minor var. pseudoamethystea. To assess the possibility of past introgressive hybridisation with $O$. amethystea, extensive sampling from populations in both the British Isles and in Northern Europe, and advanced molecular phylogenetic techniques would be required.

7) Orobanche minor var. pseudoamethystea Thorogood \& Rumsey Var. nov. Type: E. Kent, VC.15; Sandwich Bay, on sparsely vegetated sandy shingle adjacent to Prince's Golf Links, parasitic on Eryngium maritimum, 511'25.7"N 1²2'36.7"E (51.290457, 1.376862), 25/06/2020. C. Thorogood \& F. J. Rumsey s.n. BM (BM013848256)

Flowering stems simple, (5-)10-60 cm, glandular-pubescent, reddish-brown, tinged with purple. Spike lax to dense, often dense and many-flowered in taller specimens. Stem base conspicuously swollen below. Plant often forming lax clumps. Bracts 10$22 \mathrm{~mm}$, lanceolate-subulate, acuminate, equalling to just exceeding the corolla. Calyx red-brown, 10-14 mm long, unequally bifid (rarely entire). Corolla $10-18(-20)$ $\mathrm{mm}$, whitish-cream, rather flat dorsally, then inflected at the tip (not evenly curved), veined and tinted purple, weakly glandular-pubescent, upper lip bilobed with the lobes directed forwards; lobes of lower lip sub-equal, all lobes crisped and denticulate, without prominent bosses. Stamens inserted 3-3.5 mm above the corolla base; filaments sparsely hairy below. Stigma lobes pinkish-purple, partially united. Flowering period late May to early July. $n=19,2 n=38$.

Parasitic on Eryngium maritimum and other halophytes on coastal dunes and shingle in east Kent (Sandwich Bay and Deal), and locally along the coasts of southern Britain and South Wales: Isle of Wight (formerly), Devon, Cornwall, The Scillies, Channel Islands (and the north coast of France, Belgium and the Netherlands). Perhaps declining given declines in its predominant host due to increased erosion and visitor pressure.

\section{Putative hybridisation among taxa}

There is scant evidence of hybridisation in holoparasitic genera in the family Orobanchaceae. In the genus Orobanche in particular, levels of interspecific hybridisation are poorly understood. Given that most Orobanche are adapted physiologically to particular hosts, hybrids may be ill suited to, or outcompeted by, their parent species on a given host. As most Orobanche are also monocarpic and have no means of vegetative propagation any hybrids that might establish would be ephemeral, with limited opportunity for dispersal or polyploidisation. No hybridisation within the genus in the British Isles is recorded by Stace, Preston \& Pearman (2015). Species in the subsection Minores (Beck-Mannagetta) Teryokhin are so similar morphologically that any hybrids would doubtless generally be overlooked in the field; however, data indicate the possibility of hybridisation among infraspecific taxa in this group. For example morphological intermediates between subsp. maritima 
and subsp. minor exist in Cornwall, the Scillies and Channel Islands, where the former exhibits a broader than normal host and habitat range, as well as at the disjunct eastern end of its range on the chalk cliffs and dunes of Kent (Rumsey, 2007). Such populations from Cornwall and Guernsey, do indeed show evidence of gene flow between these two taxa (Thorogood et al., 2009a).

Intermediate morphotypes between $O$. minor and the closely related $O$. picridis in Kent (Fig. 2D) have long-been suspected to be hybrids. Hybrids between these species have been raised by the authors artificially (Fig. 2E) and do indeed resemble morphotypes that exist in natural populations. However, DNA sequence data have not provided conclusive evidence of hybridisation in natural populations (Thorogood $\mathrm{CJ}$, unpublished data).

Artificial hybrids have also been raised between 0 . minor and $O$. hederae on Hedera helix (Fig. 2H). These species do co-occur occasionally where their habitats merge, so the possibility of hybridisation in nature is not out of the question. Michael Jones during his doctoral research in the 1980s also raised artificial hybrids between 0 . minor and $O$. hederae (Jones, pers. comm) and furthermore he synthesised hybrids between $O$. minor and $O$. reticulata, the latter placed by Beck-Mannagetta in his grex glandulosae. Material collected in the 1880s from a long-lost population previously ascribed to $O$. reticulata from near Thirsk, N. Yorks. was tentatively suggested to be this hybrid by Foley (in litt.), a view with which we concur. Further work is needed to confirm this determination.

In summary, we conclude that hybrids are rare or impermanent in the British Isles, notwithstanding that when they do occur, they may be overlooked.

\section{Key to taxa}

1. Plant purplish throughout; spikes lax to dense; hosts and habitats various.

1. Plant always entirely

yellow.

2. Plant short (to $25 \mathrm{~cm}$ ), with a dense spike, often sub-globose apically, corollas $<12 \mathrm{~mm}$, calyx short, usually entire. Channel Islands - growing on Asteraceae tribe Cichorieae - extinct (?).................. var. hypochoeridis 2. Plant short to tall (up to c. $60 \mathrm{~cm}$ ), spike lax to moderately dense, corollas usually $>13 \mathrm{~mm}$, calyx variable - usually unequally bifid. Hosts various. But for colour, indistinguishable from 0 . minor subsp. minor. f. Iutea

3. Stem typically glandular-pubescent, short to tall (up to c. $60 \mathrm{~cm}$ ). Bracts equalling to exceeding the corolla; calyx 7.5-16 mm, entire or bifid. Lower lip with sub-equal, broadly rounded lobes, lacking prominent contrasting yellow bosses. Stigma lobes just fused, becoming distant with age. Hosts various

3. Stem glandular-puberulent, short (to $35 \mathrm{~cm}$ ). Bracts not exceeding the corolla; calyx short, 6-10 mm, often entire. Lower lip with middle lobe largest, reniform, with two prominent yellow bosses. Stigma lobes partially fused. Host Daucus carota subsp. gummifer (rarely Plantago or Asteraceae) 
4. Flowers patent (rarely sub-erect in fruit), $5-8 \mathrm{~mm}$ in diameter, variably suffused purple and typically glandular-pubescent. Hosts and habitats various...

4. Flowers conspicuously sub-erect (especially so in fruit), slender, $3.5-5 \mathrm{~mm}$ in diameter, pale and sub-glabrous. Hosts Asteraceae (especially Crepis), rarely other families. var. compositarum

5. Plant slender to robust but rarely clumped (i.e. without many stems arising from one tuber), monocarpic; corolla typically tinted pale purple; filaments slightly hairy at the base. Hosts and habitats various.

5. Plant usually clumped, perennating; corolla basally white, strongly flushed purple distally; filaments densely hairy at the base. Host Brachyglottis (occasionally other shrubs), in cultivated and landscaped environments. var. heliophila

6. Stem scarcely swollen below. Spike lax to dense; corolla often purplish, with regularly curved dorsal line (or sharply inflected at the base); upper lip not distinctly bilobed; filaments inserted 2-3.5 mm above corolla base. Hosts numerous, often Fabaceae and Asteraceae; often in disturbed or grassy habitats, coastally and inland. var. minor 6. Stem bulb-like at the base. Spike often dense; corolla ( $>15 \mathrm{~mm})$ strongly tinted purple, with flattish dorsal line, geniculate at the tip, bilobed upper lip and a high filament insertion ( $\geq 3 \mathrm{~mm}$ above the base). Parasitic on Eryngium maritimum and other halophytes, exclusively in maritime habitats

\section{var. pseudoamethystea}

\section{References}

Bean, W.J. 1980. Trees and shrubs hardy in the British Isles, Vol. IV. 8th rev. ed. London: John Murray

Beck - Mannagetta, G. (1930). Orobanchaceae in A. ENGLER, ed. Das Pflanzenreich 4 (261): 1-348.

Beck - Mannagetta, G. 1922. Orobancheae novae. Fedde, Repertorium specierum novarum regni vegetabilis 18: 33-40.

Chater A.O. \& Webb D.A. 1972. 2. Orobanche. In: Tutin, T.G., Heywood, V.H., Burgess, N.A., Moore, D.M., Valentine, D.H., Walters S.M., Webb D.M., eds., Flora Europaea 3: 286-293. Cambridge: Cambridge University Press.

Delaunay G. \& Rideau M., 2018. La réalisation du catalogue floristique d'Indre-etLoire (1908) d'Ernest-Henry Tourlet analysée au travers d'échanges épistolaires scientifiques : 2e partie - Les correspondants nationaux - Evaxiana 4, 248-266.

Domina, G. \& Danin, A. 2014. Orobanche cohenii (Orobanchaceae) a new species from Israel. Search Results. Flora Mediterranea, 24: 63-69.

Foley M. J. Y. 2001. Orobanche. - Pp. 32-72 in: Castroviejo S. \& al. (ed.), Flora iberica. Plantas vasculares de la Península e Islas Baleares 14. MyoporaceaeCampanulaceae. - Madrid: Real Jardín Botánico, C.S.I.C.

Gussone, G. 1828: Orobanche. Pp. 179-186 in Florae Siculae, Prodromus.

Hore, W. S. 1845. Description of a species of Orobanche new to Great Britain, probably Orobanche amethystea, Thuillier. The Phytologist 2: 239-240.

Kreutz, C. A. J. 1995. Orobanche, the European broomrape species. Stichting Natuurpublicaties Limburg. 
Musselman L. J., Parker C. 1982. Preliminary host ranges of some strains of economically important broomrapes (Orobanche). Economic Botany, 36: 270273.

Piwowarczyk, R. 2015. Orobanche zajaciorum (Orobanchaceae): a new species from the Caucasus. Phytotaxa, 201: 214-220.

Preston, C. D. Pearman, D. A. Dines T. D. 2002. New Atlas of the British and Irish Flora: An Atlas of the Vascular Plants of Britain, Ireland, The Isle of Man and the Channel Islands. Oxford: Oxford University Press.

Pugsley H., W. 1940. Notes on Orobanche L. Journal of Botany (London) 78: 105116.

Pujadas-Salva A. J., Crespo, M. B. 2004. A new species of Orobanche (Orobanchaceae) from south-eastern Spain. Botanical Journal of the Linnean Society, 146: 97-102.

Pujadas-Salva, A.J., Arguimbau, P.F.I. 2008. A new species of Orobanche (Orobanchaceae) from the Balearic Islands. Botanical Journal of the Linnean Society, 158: 722-729.

Pujadas-Salva, A.J., Plaza-Arregui, L., Triano-Munoz, E, Algarra-Avila, J.A. 2005. Orobanche icterica (Orobanchaceae) revisited. Botanical Journal of the Linnean Society, 148: 117-124.

Raab-Straube, E. V., Raus, T. 2018. Euro+Med-Checklist Notulae, 9. Willdenowia, 48(2): 195-220.

Regel, E. 1842. Beobachtungen über die gattung Orobanche. Allgemeine Gartenzeitung, 10:281-284.

Rumsey, J. 2007. A reconsideration of Orobanche maritima Pugsley (Orobanchaceae) and related taxa in southern England and the Channel Islands. Watsonia, 26: 473-476.

Rumsey, J., Jury, S. L. 1991. An account of Orobanche L. in Britain and Ireland. Watsonia, 18: 257-295.

Schneeweiss, G. M. 2007. Correlated evolution of life history and host range in the nonphotosynthetic parasitic flowering plants Orobanche and Phelipanche (Orobanchaceae). Journal of Evolutionary Biology, 20: 471-478.

Schneider, A. C., Colwell, A. E. L., Schneeweiss, G. M., Baldwin, B. G. 2016. Cryptic host-specific diversity among western hemisphere broomrapes (Orobanche s.l., Orobanchaceae). Annals of Botany, 118: 1101-1111.

Teryokhin, E. 1997. Weed Broomrapes - Systematics, Ontogenies, Biology, Evolution. Landshut: Aufstieg-Verlag.

Thorogood C. J., Rumsey F. J., Harris S. A., Hiscock S., J. 2008. Host-driven divergence in the parasitic plant Orobanche minor Sm. (Orobanchaceae). Molecular Ecology, 17, 4289-4303.

Thorogood C. J., Rumsey F. J., Harris S. A., Hiscock S., J. 2009a. Gene flow between alien and native races of the holoparasitic angiosperm Orobanche minor (Orobanchaceae). Plant Systematics and Evolution, 282:31-42.

Thorogood C. J., Rumsey F. J., Hiscock S., J. 2009b. Host-specific races in the holoparasitic angiosperm Orobanche minor: implications for speciation in parasitic plants. Annals of Botany, 103: 1005-1014.

Tourlet E.-H., 1903. Révision de la flore du département d'Indre-et-Loire. Bull. Soc. Bot. France, 50: 401-428. 
Zare, G., Dönmez, A. A. 2014. A new species of Orobanche (Orobanchaceae) from Turkey. Phytotaxa, 184: 148-154.

Copyright retained by author(s). Published by BSBI under the terms of the Creative Commons Attribution 4.0 International Public License.

ISSN: 2632-4970

https://doi.org/10.33928/bib.2020.02.223 


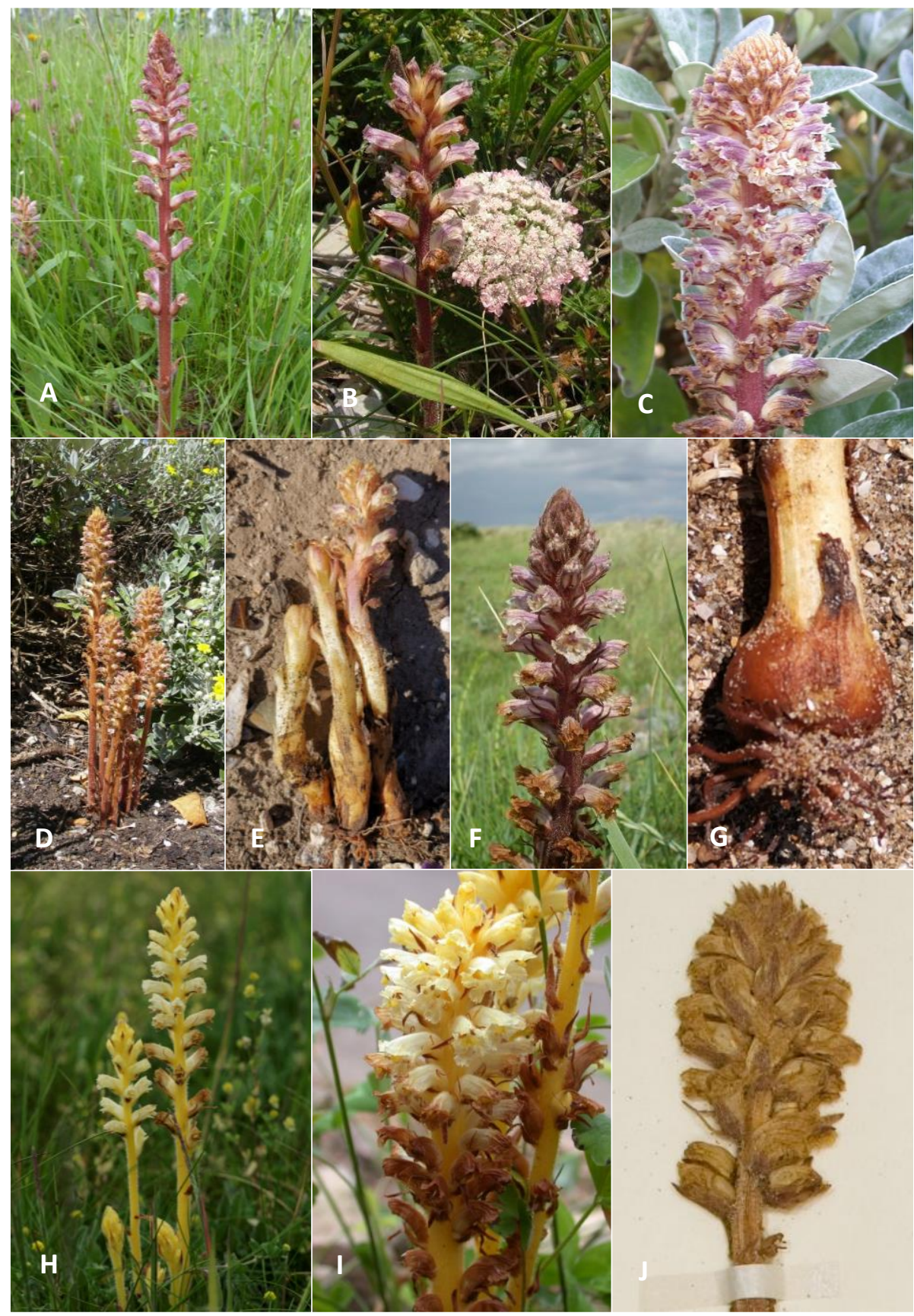

Figure 1. Intraspecific taxa of Orobanche minor in the British Isles. A. Orobanche minor subsp. minor var. minor growing with its typical host and habitat, Trifolium pratense on chalk grassland. B. O. minor subsp. maritima beside its host Daucus carota subsp. gummifer on sea cliffs in Dorset. C. 0 . minor subsp. minor var. heliophila showing the typical dense, robust inflorescence and clumped habit (D) and (E). F. O. minor subsp. minor var. pseudoamethystea growing with Crithmum maritimum at Sandwich in Kent, and uprooted to show the bulb-like stem base

(G). H. O. minor subsp. minor f. lutea. I. O. minor identified as 'var. flava' originally from Newport Docks in South Wales, in cultivation at the University of Bristol Botanic Garden (note the dense, sub-globose head similar to the following taxon). J. O. minor subsp. maritima var. hypochoeridis collected from its only known site in Jersey, where it may now be extinct. 


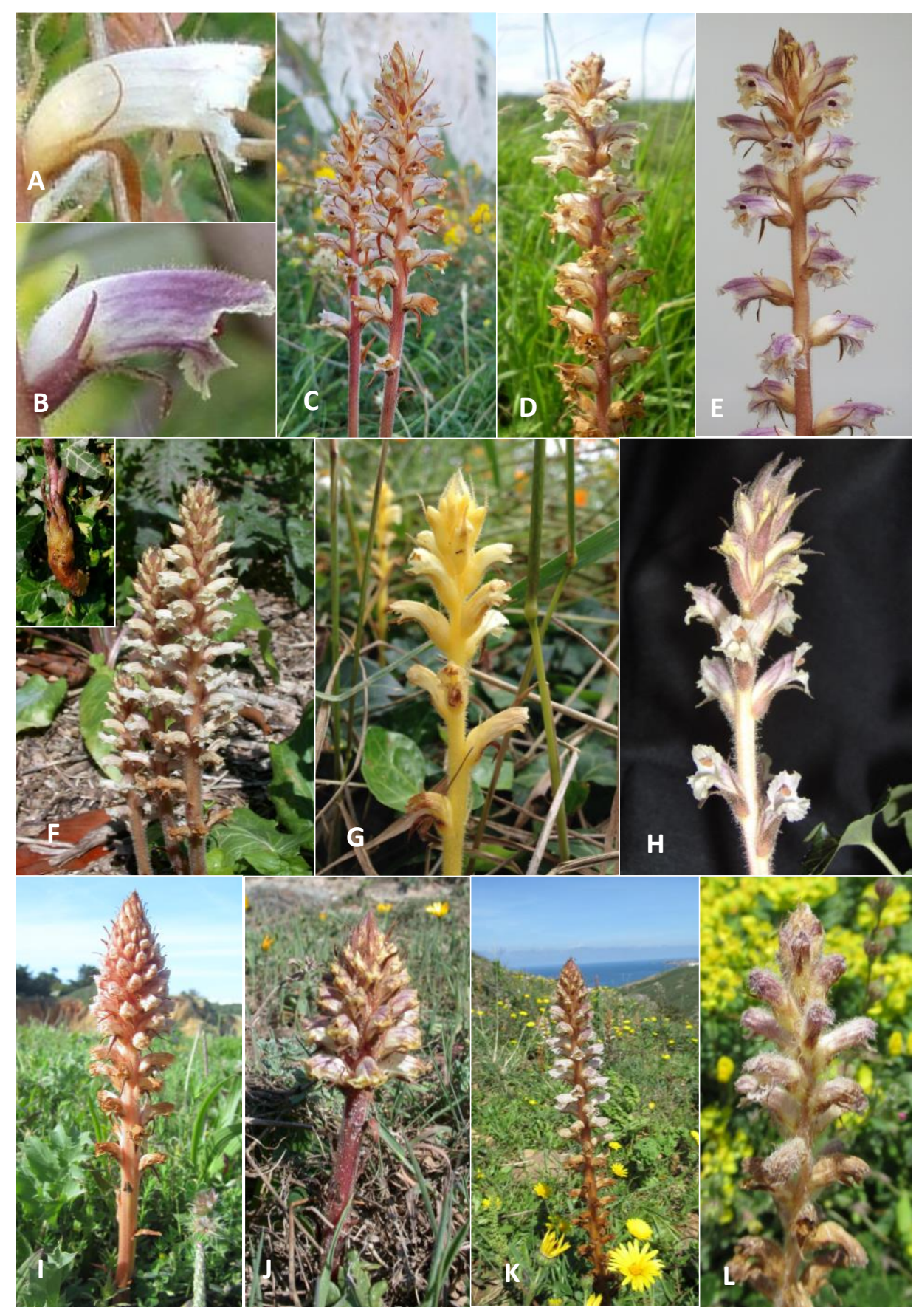

Figure 2. Closely related species in the subsection Minores (Beck) in the UK and continental Europe. A. Corolla of Orobanche picridis. B. Corolla of 0 . minor. C. 0 . picridis (habit in east Kent). D. A morphological intermediate of $\boldsymbol{O}$. picridis and $\boldsymbol{O}$. minor at St. Margaret's Bay, Kent. E. An artificial hybrid of 0 . picridis $x$. minor. F. $O$. hederae on a cultivated Eryngium (inset: stem base of specimen growing on Hedera helix). G. O. hederae f. monochroa growing on $H$. helix. H. An artificial hybrid of 0 . hederae $x$. minor; 1 . 0 . amethystea on Eryngium campestre in southern Portugal; J. Putative $O$. litorea on Plantago on the Atlantic coast of Portugal where it co-occurs with (K) 0 . calendulae on Calendula suffruticosa. $\mathrm{L}$. 0 . pubescens in Crete - a species similar to, and much confused with, 0 . minor. 


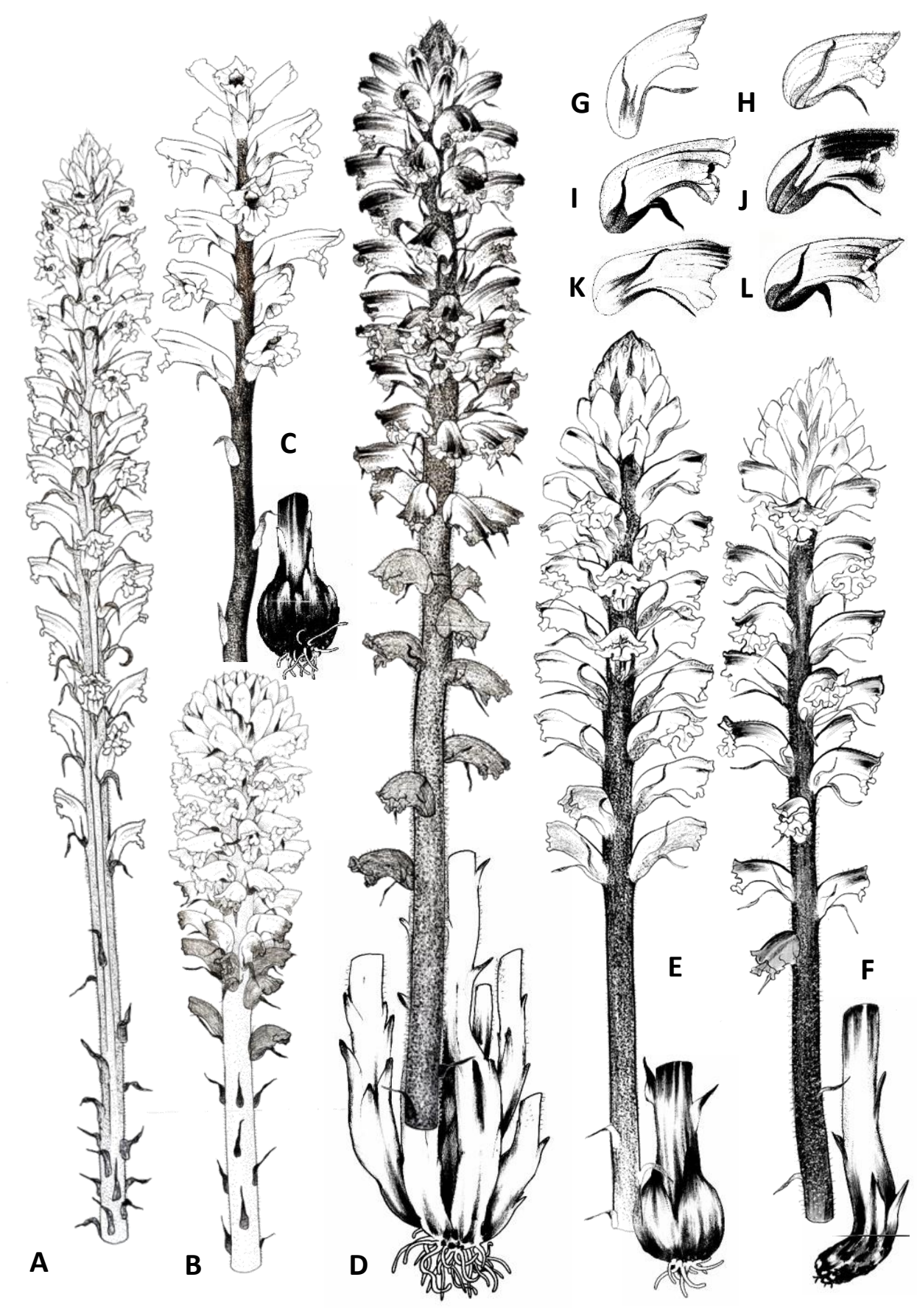

Figure 3. The intraspecific taxa of Orobanche minor in the British Isles (A-F: the habit; G-L: corolla in profile). A. $O$. minor subsp. minor var. compositarum. B. $O$. minor subsp. maritima var. hypochoeridis. C. 0 . minor subsp. maritima. D. $O$.

minor subsp. minor var. heliophila. E. O. minor subsp. minor var. pseudoamethystea. F. O. minor subsp. minor var. minor. G. 0 . minor subsp. minor var. compositarum. H. O. minor subsp. maritima var. hypochoeridis. I. 0 . minor subsp. maritima. J. O. minor subsp. minor var. heliophila. K. 0 . minor subsp. minor var. pseudoamethystea. L. 0 . minor subsp. minor var. minor. 


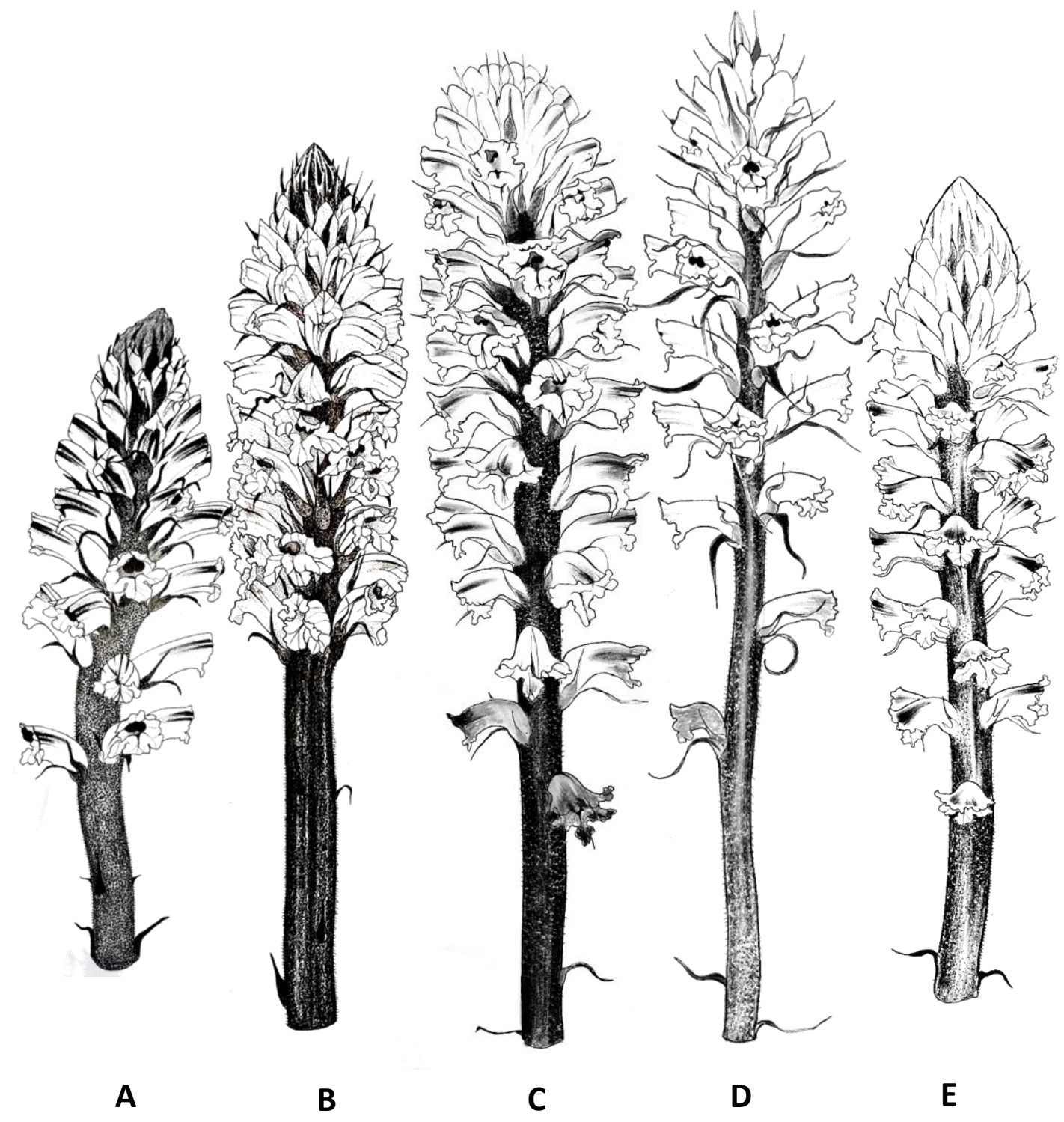

Figure 4. Closely related species in the subsection Minores (Beck) in the UK and continental Europe. A. Orobanche litorea (Sicilian form). B. Putative 0 . litorea (Portuguese form). C. O. amethystea. D. O. picridis. E. O. hederae. 